\title{
Pembelajaran Kolaboratif Jumping Tasks pada Materi “Macam-Macam Pekerjaan” Siswa Kelompok B1 Paud Santo Yoseph Kota Ternate
}

\author{
Farida Samad, Rosita Wondal, Sasmayunita \\ Universitas Khairun \\ Email: faridasamad81@gmail.com; Rositawondal@yahoo.co.id; \\ mrsasmayunita@yahoo.com
}

\begin{abstract}
Abstrak
Jumping tasks merupakan aktivitas pembelajaran dengan pemberian masalah berdasarkan tingkat kesulitanyang lebih tinggi untuk meningkatkankemampuan siswa.Penelitian ini bertujuan untuk mendeskripsikan kegiatan pembelajaran kolaboratif jumping tasks pada materi 'Macam-macam Pekerjaan' di kelompok B PAUD Santo Yoseph Kota Ternate. Teknik pengumpulan data dilakukan dengan metode observasi dan dokumenter.Analisis data kualitatif menggunakan model interaksi Miles and Huberman.Rata-rata hasil penelitian menunjukkan bahwa pembelajaran kolaboratif jumping task pada materi 'Macam-Macam Pekerjaan' di kelompok B1 PAUD Santo Yoseph Ternate sebesar 46,15\%siswa yang dapat menyelesaikan dengan kategori berkembang sesuai harapan dan sangat baik, namun 53,85\% siswa belum dapat menyelesaikan secara tuntas (masih dalam tahap mulai berkembang). Disarankan bahwa guru perlu membiasakan siswa untuk mengembangkan pola berpikir tingkat tinggi dengan memberikan tantangan (jumping task) sehingga siswa terbiasa untuk mengembangkan kemampuan berpikir dalam menyelesaikan masalah yang diberikan guru.
\end{abstract}

Kata Kunci: Kolaboratif, Jumping Task

\section{Pendahuluan}

Menyongsong abad 21 perluadanya reformasi di sekolah dan proses pembelajaran. Adapun visi dan filosofi dalam reformasi sekolahyaitukomunitas belajar (learning community). Hal ini merupakan tantangan bagi sekolah untuk membentuk komunitas belajar antara lain: pembelajaran kolaboratif di dalam kelas, pembentukan komunitas belajar professional dan kolegialitas para guru, serta partisipasi orang tua dan masyarakat. Selain itu juga pemahaman dan keterampilan guru dalam mengintegrasikan aktivitas belajarnya yang dapat mengasah keterampilan berpikit tingkat tinggi dan kritis yang dikenal dengan istilah HOTS (High Order Thinking Skill).

Pentingnya kemampuan berpikir kritis dan kreatif juga dijabarkan dan ditegaskan dalam kurikulum nasional pendidikan Indonesia yang dikenal dengan istilah HOTS (High Order Thinking Skill) dalamKurikulum 2013. Berdasarkan perspektif Kurikulum 2013, peran guru sudah bergeser dari sumber belajar utama menjadi salah satu sumber belajar, dari pemberi tahu menjadi pemicu anak untuk mencari tahu serta dari "teacher dominated learning" menjadi fasilitator dan "learning observatory" (Manabu, 2014; Nofrion, 2017). Lebih lanjut Jumping tasks merupakan aktivitas pembelajaran dengan pemberian masalah dengan kesulitanyang lebih tinggi untuk meningkatkan ("jump"/"jumping") kemampuan siswa dari kemampuan aktual ke kemampuan potensial. Masalah pada jumping task berisi materi dasar yang telah dikembangkan yaitu materi aplikasi dari konsep dasar (Manabu, 2014; Masaaki, 2012) sehingga untuk dapat menerapkan pembelajaran kolaboratif jumping tasks yang efektif perlu dilakukan perancangan desain pembelajaran tersebut.

Masalah pada jumping task berisi materi dasar yang telah dikembangkan yaitu materi aplikasi dari konsep dasar, sehingga memungkinkan pemikiran siswa dapat berkembang dengan adanya tantangan yang diberikan guru pada siswa.Praktik ini telah lama dilaksanakan di berbagai negara maju di dunia, dan salah satunya adalah Jepang.Tugas atau latihan soal yang berbasis 'jumping task' tentu saja akan mendorong 
siswa untuk tidak hanya berpikir kritis dan kreatif, tetapi mereka mampu mengembangkan sikap dan nilai-nilai kerja sama atau kolaborasi. Dengan adanya pemberian tugas 'jumping task' yang telah dirancang guru diharapkan siswa menjadi terbiasa berkolaborasi dengan teman sejawatnya, saling berinteraksi dan mengembangkan sikap saling menghargai satu sama lainnya.

Kenyataan dalam pembelajaran anak usia dini di PAUD Santo Yoseph gugus Ternate Tengah pada umumnya guru cenderung menggunakan metode diskusi dan metode ceramah dalam proses pembelajaran yang dilakukan di kelas TK B1, sehingga belum nampak terjadi proses saling belajar antar anggota kelompok di dalam kelompok yang telah dibagi oleh guru sehingga pembelajaran dalam kelompok hanya didominasi oleh satu atau dua orang yang aktif. Pembelajaran kolaboratif juga perlu dikembangkan di dalam proses pembelajaran anak usia dini yang meliputi: pembelajaran otentik (pembelajaran yang sejalan dengan karateristik mata pelajaran), hubungan saling belajar (hubungan saling mendengarkan), dan pembelajaran yang terdapat lompatan/jumping (pembelajaran yang bersifat kreatif dan menantang).

Hasil penelitian yang dilakukan oleh Nofrion (2017) menunjukan bahwa penerapan metode "jumping task" berhasil meningkatkan aktivitas belajar siswa dengan tingkat capaian di atas $80 \%$ pada semua jenis aktivitas belajar yang diobservasi. Hasil penelitian serupa oleh Anwar dkk (2017) bahwa terdapat perbedaan keterampilan berpikir kritis dan hasil belajar kognitif antara siswa yang belajar menggunakan collaborative learning dengan teknik jumping task dan siswa yang belajar menggunakan collaborative learning. Keterampilan berpikir kritis dan hasil belajar siswa yang belajar menggunakan colaborative learning lebih rendah dari pada siswa yang belajar menggunakan collaborative learning dengan teknik jumping task, hal ini disebabkan oleh penggunaan teknik jumping task yang meningkatkan kegiatan kolaborasi dalam menyelesaikan masalah bersama.

Peneliti melakukan observasi pada pelaksanaan pembelajaran anak usia dini tahun ajaran 2018-2019 yang dilakukan dikelompok B PAUD Santo Yoseph materi 'Pekerjaan' sub tema 'Macam-Macam Pekerjaan' dengan model pembelajaran kolaborasi kelompok menunjukan bahwa kegiatan inti dalam jumping task antara lain: menyusun puzzle gambar 'polisi' dan kegiatan story telling tentang 'polisi sahabat anak'. Selain itu, nampak adanya perbedaan karakter peserta didik kelompok B1 dengan berkemampuan akademik tinggi, sedang dan rendah.Ada beberapa peserta didik yang mau membantu temannya untuk memahami dan menyelesaikan materi pembelajaran.Namun, ada beberapa yang lebih memilih asik bermain sendiri di dalam kelas saat guru menerangkan materi yang telah dipahaminya dan kemudian ikut serta kembali dalam pembelajaran, Dengan demikian, perlu upaya untuk mengoptimalkan pembelajaran kolaboratif yang dapat memfasilitasi semua siswa untuk belajar dengan efektif.Pemberian masalah pada jumping task akan memotivasi siswa untuk berpikir lebih luas dan mendalam dalam mencari solusi yang beragam. Kegiatan memecahkan masalah dapat membuat siswa sebagai pemecah masalah yang baik, sehingga siswa tidak hanya dipersiapkan untuk memiliki kemampuan berpikir sains tetapi juga kemampuan memecahkan masalah dengan percaya diri terhadap tantangan hidup yang dihadapinya.

Berdasarkan hal ini, peneliti mendeskripsikan kegiatan pembelajaran kolaboratif jumping task pada materi 'Macam-Macam Pekerjaan' siswa Kelompok B1 PAUD Santo Yoseph Ternate. 


\section{Landasan Teori}

\section{Pembelajaran Kolaboratif Jumping Task}

Rustaman (2003) menjelaskan bahwa pembelajaran merupakan proses interaksi antara pengajar, siswa, dan media pembelajaran, dengan adanya interaksi tersebut, siswa dapat secara aktif mengembangkan keterampilan dan pola pikir dalam belajar. Pembelajaran berlangsung secara interaktif, inspiratif, menyenangkan, menantang, serta dapat memotivasi siswa dalam mencapai kompetensi yang diharapkan.Lebih lanjut Manabu (2014) mengemukakan bahwa pembelajaran yang menyenangkan, inovatif dan menantang merupakan pembelajaran yang mengarah ke sekolah model abad 21.Sekolah modern dibentuk berdasarkan prinsip daar pencapaian simultan antara kualitas (quality) dan kesetaraan (equality). Misi dari komunitas belajar di sekolah adalah menjamin hak belajar setiap anak dan meningkatkan kualitas pembelajaran (Manabu, 2014).

Pembelajaran kolaboratif merupakan penerapan dari teori Vygotsky mengenai Zone of Proximal Development (ZPD) dan teori komunikasi oleh Dewey.Aktivitas pembelajaran kolaboratif dikenal sebagai praktek konstruksi sosial yaitu pemahaman siswa dapat dikonstruk melalui sosiokultural dengan kegiatan komunikasi interaktif (kolaborasi) antar siswa dalam memecahkan masalah yang tidak dapat diselesaikan hanya dengan satu siswa saja, yaitu melalui pertukaran pendapat terhadap masalah tersebut (Masaaki, 2012).Teori ZPD menitikberatkan pada pencapaian pengetahuan yang dilakukan dengan memberikan bantuan, bantuan yang diberikan kepada siswa.Bantuan yang diberikan pada siswa tidak harus dilakukan oleh guru, melainkan dapat dilakukan oleh teman sebaya dikelasnya yang memiliki kemampuan akademis lebih tinggi.Bantuan guru berupa pertanyaan, arahan, maupun petunjuk untuk membimbing siswa mencapai pemahaman konsep yang diinginkan. Sedangkan bantuan dari teman sebaya adalah saling bekerja sama untuk menyelesaikan tugas yang dilakukan melalui kegiatan diskusi dalam kelompok kecil.

Berdasarkan hasil penelitian Gifford dan Arvin (2009), pembelajaran kolaboratif melalui kelompok yang heterogen dapat mempercepat pembelajaran dalam kelompok, serta memperbaiki kinerja dan keseluruhan perilaku siswa dalam kelompok.Sedangkan pemberian masalah yang kompleks dapat meningkatkan efisiensi belajar pada tiap anggota kelompok (Kirschner, Fred dan Paul, 2011).Siswa dengan akademis tinggi, sedang, maupun rendah dapat mengalami hambatan epistemologis sehingga diperlukan pembelajaran kolaboratif yang dapat memfasilitasi semua siswa untuk belajar dengan efektif.

Pembelajaran kolaboratif jumping tasks merupakan pembelajaran yang menguntungkan semua siswa baik siswa dengan akademis tinggi, sedang, maupun rendah. Pemberian masalah pada jumping task akan memotivasi siswa untuk berpikir lebih luas dalam mencari solusi yang beragam. Kegiatan memecahkan masalah dapat membuat siswa sebagai pemecah masalah yang baik, sehingga siswa tidak hanya dipersiapkan untuk memiliki kemampuan berpikir sains tetapi juga kemampuan memecahkan masalah dengan percaya diri terhadap tantangan hidup yang dihadapinya (Rosbiono, 2007).Jumping tasks merupakan aktivitas pembelajaran dengan pemberian masalah dengan kesulitanyang lebih tinggi untuk meningkatkan ("jump"/"jumping") kemampuan siswa dari kemampuan aktual ke kemampuan potensial. Masalah pada jumping task berisi materi dasar yang telah dikembangkan yaitu materi aplikasi dari konsep dasar (Manabu, 2014; Masaaki, 2012) sehingga untuk dapat menerapkan 
pembelajaran kolaboratif jumping tasks yang efektif perlu dilakukan perancangan desain pembelajaran tersebut.

\section{Lesson Study}

Lesson Study (LS) merupakan suatu model pembinaan pekerjaan pendidik melalui pengkajian pembelajaran secara kolaboratif dan berkelanjutan, berlandaskan prinsip-prinsip kesejawatan dan mutual learning untuk membangun komunitas belajar.Lesson Study adalah suatu pendekatan peningkatan kualitas pembelajaran yang awal mulanya berasal dari Jepang.Kata atau istilah Jepang untuk ini adalah "Jugyokenkyu" (Yoshida, 1999 dalam Lewis, 2002). Melalui lesson study, keempat kompetensi pendidik yakni kompetensi kepribadian, kompetensi sosial, kompetensi profesional, dan kompetensi pedagogik akan semakin meningkat.

Lesson study adalah strategi untuk meningkatkan kualitas belajar dan mengajar guru dengan mempelajari proses belajar mengajar yang telah dilaksanakan secara berkesinambungan. Menurut Tjipto Subadi (2010)lesson study adalah suatu model pembinaan pekerjaan guru melalui belajar mengajar (pengkajian pembelajaran) secara kolaboratif. Hasil positif yang di rasakan oleh guru setelah menerapkan lessonstudy di kelas, penelitian Khotimah dan Masduki, 2016 menunjukkan dengan lesson studyguru dapat menyajikan permasalahan yang nyata dalam pembelajaran, merencanakan strategi serta menyusun instrument penilaian.

Cerbin dan Kopp (2009) mengemukakan bahwa lesson study memiliki 4 (empat) tujuan utama, yaitu untuk: (1) memperoleh pemahaman yang lebih baik tentang bagaimana siswa belajar dan guru mengajar; (2) memperoleh hasil-hasil tertentu yang dapat dimanfaatkan oleh para guru lainnya, di luar peserta lesson study; (3) meningkatkan pembelajaran secara sistematis melalui inkuiri kolaboratif. (4) membangun sebuah pengetahuan pedagogis, di mana seorang guru dapat menimbah pengetahuan dari guru lainnya.

\section{Metode Penelitian}

\section{Jenis dan Rancangan Penelitian}

Penelitian ini menggunakan pendekatan kualitatif dengan rancangan jenis penelitian deskriptif. Dengan landasan berpikir bahwa penelitian ini bermaksud untuk mendeskripsikan tentang pembelajaran kolaboratif jumping tasks pada materi 'MacamMacam Pekerjaan' siswa Kelompok B1 PAUD Santo Yoseph Ternate.

\section{Subyek dan Lokasi Penelitian}

Subyek dalam penelitian ini adalah peserta didik kelompok B1 usia 5-6 tahun yang telah mendapatkan pembelajaran pada materi 'Macam-Macam Pekerjaan'di PAUD Santo Yoseph Ternate yang jumlah 13 siswa. Waktu penelitian ini dilaksanakan pada bulan April-Juni tahun ajaran 2018/2019.

\section{Data dan Sumber Data}

Data yang diperlukan dalam penelitian ini antara lain; data yang bersumber dari PAUD Santo Yoseph Ternate dan sumber data lain yang terkait dengan kondisi pembelajaran sebagaimana disebutkan. Subyek yang dimintai informasiadalah pendidik. Selain itu, untuk melengkapi data/informasi di atas, peneliti memerlukan dokumen sehubungan dengan pelaksanaan pembelajaran anak berbasis lesson studydi kelas.Adapun subyek yang dipilih dalam penelitian ini adalah guru PAUD yang menjadi guru model dan mengajar di kelas yang telah ditetapkan sebagai subjek penelitian yang mengajar pada peserta didik kelompok B yang diberi pembelajaran kolaboratif jumping tasks pada materi 'Macam-Macam Pekerjaan' yaitu 13 orang di kelompok B1 PAUD 
Santo Yoseph Ternate. Penentuan subyek penelitian dilakukan dengan menggunakan purposive sampling, yaitu pemilihan sampel dengan pertimbangan: a) subyek penelitian terlibat langsung dalam proses pembelajaran kolaboratif b) pihak yang menguasai permasalahan, memiliki data dan bersedia memberi informasi. Tujuannya untuk mendapatkan informasi yang akurat sesuai dengan pedoman yang ditetapkan.

\section{Teknik Pengumpulan Data}

Sesuai dengan jenis data dan sumber data yang diperlukan, pengumpulan data penelitian ini dilakukan dengan metode sebagai berikut.

\section{a. Metode Observasi}

Observasi digunakan untuk melakukan pengamatan terhadap gambaran secara langsung aktivitas siswa secara holistik selama proses pembelajaran, implementasi rancangan pembelajaran yang telah dibuat, serta memperoleh gambaran "jumping"yang terjadi pada peserta didik kelompok B1 PAUD Santo Yoseph Ternate. Berikut adalah indikator penilaian lembar observasi:

Tabel 1. Kegiatan Jumping Task

\begin{tabular}{|l|l|l|}
\hline \multicolumn{3}{|c|}{ Jumping Task } \\
\hline $\begin{array}{l}\text { Analisis } \\
\text { peristiwa }\end{array}$ & $\begin{array}{l}\text { Mengatasi } \\
\text { Permasalahan }\end{array}$ & $\begin{array}{l}\text { Mengemukakan } \\
\text { Ide Kreatif }\end{array}$ \\
\hline \multicolumn{3}{|c|}{ Menyusun Puzzle 'polisi' } \\
\hline \multicolumn{3}{|c|}{ Story Telling 'polisi sahabat anak' }
\end{tabular}

Tabel 2.Kriteria penilaian:

\begin{tabular}{|c|c|l|}
\hline Kriteria & $\begin{array}{c}\text { Skor } \\
\text { Perolehan }\end{array}$ & \multicolumn{1}{|c|}{ Penafsiran } \\
\hline BSB & $>75 \leq 100$ & $\begin{array}{l}\text { Pada indikator, anak dapat mandiri tahu/melakukan } \\
\text { bahkan menolong orang lain }\end{array}$ \\
\hline BSH & $>50 \leq 75$ & Pada indikator, anak dapat mandiri tahu/melakukan \\
\hline MB & $>25 \leq 50$ & $\begin{array}{l}\text { Pada indikator, anak dapat mandiri tahu/melakukan } \\
\text { namun sesekali meminta bantuan guru }\end{array}$ \\
\hline BM & $\leq 25$ & $\begin{array}{l}\text { Pada indikator, anak belum dapat mandiri } \\
\text { tahu/melakukan }\end{array}$ \\
\hline
\end{tabular}

b. Metode Dokumenter

Adapun dokumentasi yang dikumpulkan dalam penelitian ini adalah pembelajaran kolaboratif jumping taskspada materi 'Macam-Macam Pekerjaan' siswa Kelompok B1 PAUD Santo Yoseph Ternate dalam bentuk video pembelajaran, sumber ajar guru mengenai materi'Macam-Macam Pekerjaan', lembar kerja anak, silabus kurikulum 2013 PAUD, dan RPPH yang biasa digunakan oleh guru dan penilaian siswa kelompok B semester genap.

\section{Teknik Analisis Data}

Teknik analisis data yang peneliti gunakan dalam penelitian ini merupakan kegiatan yang bertujuan untuk mengolah data- data yang telah didapatkan oleh peneliti melalui kegiatan observasi dan studi dokumentasi yang dilakukan di PAUD Santo Yoseph Kota Ternate dalam hubungannya dengan pembelajaran kolaboratif jumping tasks. Setelah data dikumpulkan, langkah selanjutnya peneliti melakukan proses analisis data. Teknik yang digunakan adalah analisis data kualitatif dengan langkah- langkah sebagai berikut: 


\section{a. Reduksi Data}

Reduksi data adalah proses pemilihan, pemungutan, penyederhanaan, pengabstrakan dan transformasi data hasil penelitian tentang pembelajaran kolaboratif jumping tasks pada materi 'Macam-Macam Pekerjaan' siswa Kelompok B1 PAUD Santo Yoseph Ternate dalam mereduksi data, peneliti dipandu oleh tujuan yang akan dicapai.

b. Penyajian Data

Dalam penelitian kualitatif, penyajian data dilakukan dalam bentuk uraian singkat, bagan, gambar/skema atau beberapa tabel yang dirancang untuk menyusun informasi agar dapat dimengerti.Penyajian data adalah informasi yang tersusun dan memberikan kemungkinan tentang adanya penarikan kesimpulan dan pengambilan tindakan.Data yang disajikan dalam penelitian ini merupakan kata-kata verbal tentang pembelajaran kolaboratif jumping tasks pada materi 'Macam-Macam Pekerjaan' siswa Kelompok B1 PAUD Santo Yoseph Ternate.

c. Verifikasi dan penarikan kesimpulan

Kegiatan vertifikasi berlangsung selama berlangsungnya penelitian. Kegiatan ini dimaksudkan untuk memvertifikasi data dan mempertimbangkan kesimpulan yang akan diambil apakah betul-betul telah memenuhi aspek obyektivitas. Dalam melaksanakan langkah ini, peneliti menempuh langkah- langkah yakni trianggulasi data dan member check.

\section{Hasil Penelitian dan Pembahasan}

\section{A. Hasil Penelitian}

Pelaksanaan jumping tasks pada materi 'Macam-Macam Pekerjaan', berikut hasil pengamatan peneliti terkait tahapan-tahapan yanga ada dalam pelaksanaan lesson study.

\section{Plan (Perencanaan)}

Tahap awal persiapan dimulai dengan melakukan identifikasi masalah pembelajaran serta altenatif solusi pembelajaran yang dipilih di kelompok B1. Berdasarkan pengalaman, anak sulit untuk mengurutkan kata. Kegiatan jumping tasks berupa menyusun puzzle gambar 'polisi' yang diakhiri dengan kegiatan story telling 'polisi sahabat anak'. Untuk kegiatan belajar mengajar yang digunakan adalah model pembelajaran kelompok dimana anak-anak dibagi menjadi beberapa kelompok dan masing-masing kelompok melakukan kegiatan yang berbeda-beda.Dalam satu kali pertemuan ini tentunya anak harus menyelesaikan 2-3 kegiatan dalam kelompok secara bergantian dengan tuntas.

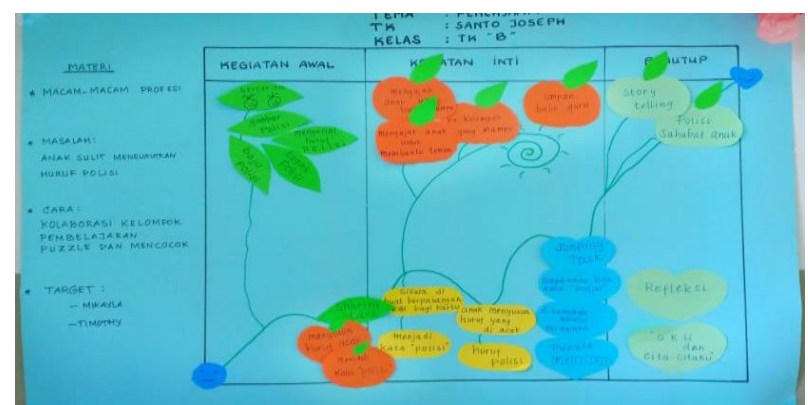

Gb1. Lesson design (LD) pembelajaran kelompok B1 materi

'Macam-Macam Pekerjaan' 


\section{Do (Pelaksanaan)}

Tahap ini dilaksanakan setelah semua perangkat pembelajaran siap dilakukan. Pada pertemuan ini, kegiatan main dilaksanakan dengan model pembelajaran kelompok yang disesuaikan dengan RPPH yang didesain bersama-sama oleh guru model dan tim observer. Pembelajaran pagi itu dimulai dengan berbaris rapi, berdoa bersama, bernyanyi lagu 'lihat bapak polisi' mengucap syair 'polisi', melakukan yel-yel tepuk semangat baru dan dilanjutkan dengan anak-anak yang berlari sambil melompat. Pada kegiatan apersepsi yaitu guru bercakap-cakap tentang macam pekerjaan, selanjutnya guru meminta siswa untuk menyebutkan apa saja tugas polisi dan polisi mengatur lalu lintas. Guru menyampaikan tujuan pembelajaran yang akan dilaksanakan hari itu adalah anak dapat menyusun kata polisi dengan tepat dan menceritakan 'polisi sahabat anak'. Selanjutnya, sebelum guru model membagi kelas dalam beberapa kelompok, guru menjelaskan kegiatan atau hal-hal yang berkaitan dengan tugas masing-masing kelompok secara klasikal.

Saat pengerjaan LKA jumping task, anak diperbolehkan berdiskusi dalam kelompoknya masing-masing guna menyelesaikan puzzle gambar 'polisi' yang dilakukan dalam bentuk permainan untuk membentuk gambar 'polisi'. Setelah pengerjaan LKA berakhir, pembelajaran dilanjutkan kembali dengan story telling 'polisi sahabat anak' oleh siswa.Siswa sudah nampak aktif dalam pembelajaran meskipun situasi pembelajaran masih terkesan tegang dan kaku, namun mereka nampak serius mengikuti materi yang disampaikan oleh guru model.

\section{See (Refleksi)}

Setelah selesai proses pembelajaran, selanjutnya dilakukan kegiatan refleksi. Pada awal kegiatan refleksi, guru model diberikan kesempatan terlebih dahulu untuk menyampaikan kesan-kesan yang dirasakan saat mengajar terutama saat pembelajaran tugas jumping pada siswa kelompok B1 selama implementasi rancangan pembelajaran. Selanjutnya, para observer secara bergantian menyampaikan tanggapan dan kesankesannya terhadap pembelajaran yang telah diamatinya.Dalam kegiatan ini terungkap bahwa guru model dan siswa sudah melaksankan pembelajaran dengan baik mulai persiapan sampai pada pelaksanaannya. Berikut ini akan dijelaskan pelaksanaan pembelajaranjumping tasks pada materi 'Macam-Macam Pekerjaan' yang dinilai dari beberapa hal antara lain:

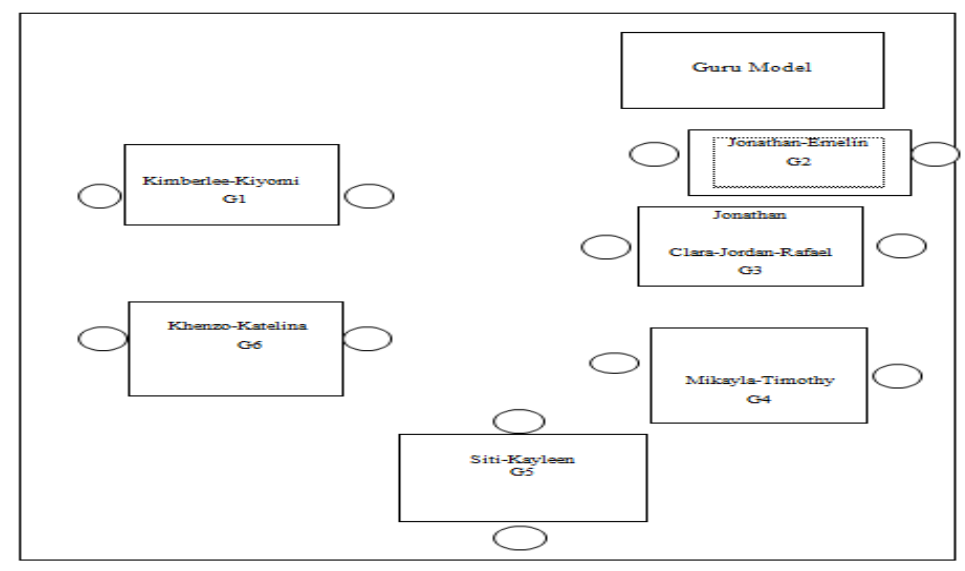

Gb 2. Denah kelas B1- PAUD Santo Yoseph 
Kegiatan jumping task diberikan masih pada saat kegiatan inti di kelas berupa menyusun puzzle gambar 'polisi' dan pemberian pengalaman belajar berupa kegiatan story telling tentang 'polisi sahabat anak'. Pada tugas jumping ini, guru model melakukannya dengan memanfaatkan pengetahuan awal yang sudah ada pada siswa sehingga mereka mampu untuk memformulasi pengetahuan baru, memecahkaan masalah, maupun mampu berpikir kritis.

a. Menganalisis peristiwa berdasarkan masalah dan memberi argumentasi

Pada kegiatan menyusun puzzle gambar 'polisi', kelompok Kimberlee dan Kiyomi terutama Kimberlee cukup cekatan dalam menyelesaikan puzzle, berbeda dengan Kiyomi yang terlihat lama dan sering melamun. Sedangkan kelompok lainnya JordanClara dan Rafael, Janatan dan emelin, kelompok Mikayla dan Timothy, kelompok Kayleen dan Siti serta kelompok Khenzo dan Katelina cukup berusaha saling bekerjasama satu dan lainnya dalam kelompok untuk menyelesaikan puzzle tersebut. Namun, berdasarkan pengamatan bahwa Mikayla menunjukkan hasil karya puzzle yang rapi dibandingkan teman-temannya lainnya di kelas.Di bawah ini adalah salah satu contoh tugas jumping oleh siswa.

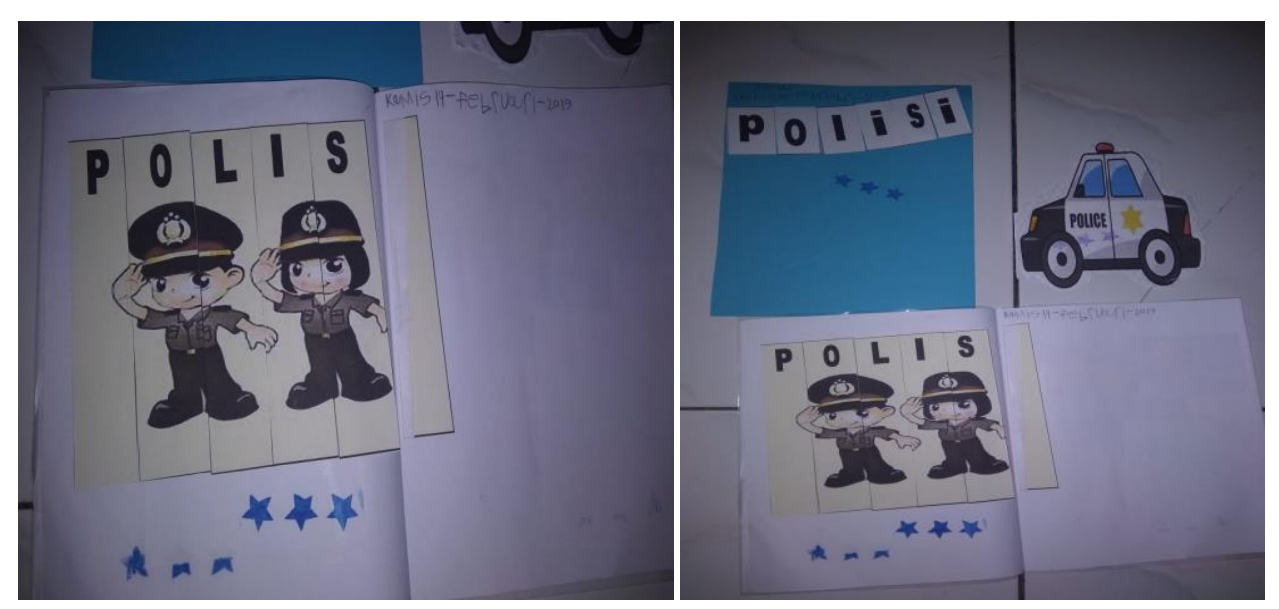

Gb 3. Hasil jumping task

Sebelum kegiatan pada hari itu berakhir, guru model melanjutkan dengan kegiatan story telling yang merupakan salah satu kegiatan yang bisa mengembangkan kecerdasan bahasa anak.Anak-anak tampak senang dan kelas begitu ramai. Dengan serius merekapun mendengarkan guru model yang membawakan kisah tentang 'polisi sahabat anak'. Cerita ini tampaknya sangat menarik perhatian anak-anak hingga mereka terus mengikuti cerita dengan antusias.Kelompok Jordan-Clara dan Rafael khususnya Jordan mampu menganalisis bahwa mereka tidak perlu takut dengan polisi. Jordanpun mampu mendeskripsikan dengan baik tentang rambu lalu lintas, berkendaaran dengan memakai helm sangat penting, tugas polisi yang mampu menangkap pencuri dan mengatur lalu lintas agar jalan tidak macet. Pada kelompok Emelin dan Jonatan, Jonatan memiliki kemampuan verbal yang sama baiknya dengan Jordan. Jonatan mamapu berbagi pengalaman tentang polisi sahabat anak.

Demikian halnya dengan Mikayla dan Kayleen yang sangat berkonsentrasi dan memiliki kemampuan verbal yang baik sehingga mampu bercerita tentang 'polisi sahabat anak' dengan ekspresif.Kemampuan mengajukan pertanyaan oleh keduanya sangat baik yang mana beberapa pertanyaan yang diajukan sudah menggunakan kalimat 
tanya apa, siapa dan mengapa. Tentunya hal ini membukikan bahwa anak juga sudah memasuki tahapan perkembangan bahasa yakni memahami sintaksis.Selain itu, ini menunjukkan bahwa siswa telah memasuki tahapan yang lebih tinggi lagi dalam perkembangan bahasa yakni tahapan perluasan produksi yang biasanya nampak ketika sudah mampu memproduksi bahasa dalam kesehariannya termasuk dalam berbicara dengan kalimat panjang, mengajukan pertanyaan, mengisahkan sebuah cerita dan melakukan.

Lain halnya dengan Siti dan Timothy memiliki konsentrasi yang minim, kurang antusias dan kemampuan verbal komunikasi yang mulai berkembang. Diantara temanteman di kelompok B1, keduanya terlihat kurang ekspressif baik saat menceritakan maupun sedang mendengarkan.

b. Mengatasi permasalahan

Kemampuan menjawab pertanyaan meningkat melalui kegiatan tanya jawab selama aktivitas jumping taskdalam metode story telling. Dalam metode story telling tersebut semua siswa kelompok B1 distimulasi oleh guru model untuk mengungkapkan jawaban dari pertanyaan yang menggunakan kata apa, siapa dan mengapa terkait 'polisi sahabat anak'. Anak sudah mampu mengungkapkan jawaban sesuai dengan pertanyaan.Jawaban diungkapkan melalui kalimat sederhana yang dipahami.seperti yang disampaikan oleh kelompok Jordan-Clara dan Jonatan tentang pentingnya helm saat berkendaraan agar tidak jatuh di jalan.

\section{c. Menemukan ide kreatif}

Kreativitas muncul pada diri siswa kelompok B1 yang memiliki rasa ingin tahu, imajinasi dan eksplorasi. Diantaranya adalah Jordan, Mikayla dan Jonathan, Kayleen dalam kegiatan storytelling tentang 'polisi sahabat anak'. Mereka kreatif dan selalu mencari serta mampu menemukan jawaban, dengan kata lain mereka senang memecahkan masalah dalam aktivitas jumping task berupa story telling. Mereka juga ingin memuaskan rasa keingintahuannya melalui berbagai cara, seperti bereksplorasi dan banyak mengajukan pertanyaan kepada guru model. Disinilah guru model mestinya harus lebih banyak memberikan kesempatan. Dengan kata lain, siswa yang kreatif dalam pembelajaran kelompok selalu mencari dan menemukan jawaban, seperti senang memecahkan masalah. Permasalahan yang muncul selalu dipikirkan kembali, disusun kembali, dan selalu berusaha menemukan hubungan yang baru, mereka selalu bersikap terbuka terhadap sesuatu yang baru dan tidak diketahui sebelumnya. Dalam proses mendengarkan cerita tentang 'polisi sahabat anak' dan bertanya tentu saja banyak memunculkan ide-ide baru dari anak-anak. Ketika guru model bercerita dengan media gambar 'polisi' yang ada ini tentu akan membangun hubungan anak dengan guru dan 'polisi' menjadi lebih baik. Cerita yang disampaikan oleh guru model saat jumping task menjadi strategi berinteraksi antara siswa dalam kelompok dan guru model. Siswa lebih bersemangat dalam memahami isi cerita 'polisi sahabat anak' dengan media kartu dan gambar 'polisi' yang dibuat sendiri oleh guru model. Semangat ini juga yang akan mendorong anak dalam mengembangkan ketrampilannya dalam bertanya.

\section{B. Pembahasan}

Gifford dan Arvin (2009) menjelaskan bahwa pembelajaran kolaboratif melalui kelompok yang heterogen dapat mempercepat pembelajaran dalam kelompok, serta memperbaiki kinerja dan keseluruhan perilaku siswa dalam kelompok.Sedangkan pemberian masalah yang kompleks dapat meningkatkan efisiensi belajar pada tiap anggota kelompok (Kirschner, Fred dan Paul, 2011).Siswa dengan akademis tinggi, 
sedang, maupun rendah dapat mengalami hambatan epistemologis sehingga diperlukan pembelajaran kolaboratif yang dapat memfasilitasi semua siswa untuk belajar dengan efektif.

Pembelajaran kolaboratif jumping tasks merupakan pembelajaran yang menguntungkan semua siswa baik siswa dengan akademis tinggi, sedang, maupun rendah. Pemberian masalah pada jumping task akan memotivasi siswa untuk berpikir lebih luas dalam mencari solusi yang beragam. Kegiatan memecahkan masalah dapat membuat siswa sebagai pemecah masalah yang baik, sehingga siswa tidak hanya dipersiapkan untuk memiliki kemampuan berpikir sains tetapi juga kemampuanmemecahkan masalah dengan percaya diri terhadap tantangan hidup yangdihadapinya (Rosbiono, 2007).Jumping tasks merupakan aktivitas pembelajaran dengan pemberian masalah dengan kesulitanyang lebih tinggi untuk meningkatkan ("jump"/jumping") kemampuan siswa dari kemampuan aktual ke kemampuan potensial. Masalah pada jumping task berisi materi dasar yang telah dikembangkan yaitu materi aplikasi dari konsep dasar (Manabu, 2014; Masaaki, 2012) sehingga untuk dapat menerapkan pembelajaran kolaboratif jumping tasks yang efektif perlu dilakukan perancangan desain pembelajaran tersebut.

Berdasarkan hasil pembelajaran yang dilaksanakan pada siswa kelompok B1 yang menjadi subyek penelitian dan mengacu pada Rencana Pelaksanaan Pembelajaran Harian (RPPH) didapatkan hasil kegiatan main siswa dilaksanakan melalui 2 tahapan kegiatan inti pembelajaran, kedua tugas dalam kegiatan lesson study menekankan pada aktivitas siswa dalam pembelajaran. Namun yang menjadi perbedaannya adalah pada tingkat kesulitan tugas yang diberikan.Jumping tasks adalah tugas dengan level yang lebih tinggi (advanced), yang diharapkan dapat memacu siswa untuk belajar dan berpikir lebih mendalam, sehingga tuntutan tingkat pembelajaran pada kelas tersebut menjadi lebih berkualitas.Berikut akan dijelaskan aktivitas pembelajaran kelompok B1 sebagai berikut:

Tabel 3.Perkembangan Aktivitas Belajar

\begin{tabular}{llc}
\hline \multicolumn{1}{c}{ No } & \multicolumn{1}{c}{ Nama siswa } & $\begin{array}{c}\text { Jumping task } \\
\text { (Kategori) }\end{array}$ \\
\hline Grup1 & Kiyomi & MB \\
1 & Kimberlee & BSH \\
2 & & \\
\hline Grup 2 & Jordan & BSB \\
1 & Clara & MB \\
2 & Jonathan & MB \\
3 & & \\
\hline Grup 3 & Khenzo & MB \\
1 & Katelina & MB \\
2 & & \\
\hline Grup 4 & Mikayla & BSB \\
1 & Timothy & MB \\
2 & & MB \\
\hline Grup 5 & Siti & BSB \\
1 & Kayleen & \\
2 & & \\
\hline Grup 6 & &
\end{tabular}


Volume 6 Nomor 2

\begin{tabular}{lll}
\hline 1 & Emelin & BSH \\
2 & Jonathan & BSB \\
\hline
\end{tabular}

Berdasarkan tabel 3, hasil rata-rata siswa yang tuntas menyelesaikan jumping task hanya 46,15\% atau 6 siswa (Jordan, Mikayla, Jonathan, Kayleen, Emelin dan Kimberlee), sedangkan 53,85\% belum bisa menyelesaikan dengan tuntas. Pada pemberian tugas jumping yakni meyusun puzzle gambar 'polisi' dan kegiatan story telling 'polisi sahabat anak' masih perlu bimbingan guru, dalam hal memberikan tugas yang dapat memacu siswa untuk berpikir lebih mendalam, lebih kritis, lebih inovatif dan kreatif. \

\section{Simpulan}

Berdasarkan hasil penelitian yang telah diuraikan, dapat disimpulkan bahwapembelajaran kolaboratif jumping task pada materi 'Macam-Macam Pekerjaan' di kelompok B1 PAUD Santo Yoseph Ternate sangat efektif menggunakan pembelajaran jumping task.6 kelompok, Rata-rata 46,15 \% siswa yang dapat menyelesaikan jumping task, sedangkan 53,85 belum dapat menyelesaikan secara tuntas. Dengan adanya pembelajaran kolaboratif jumping task dapat meningkatkan kemampuan siswa sekolah PAUD dalam memahami materi 'Macam-Macam Pekerjaan'. 


\section{Daftar Pustaka}

Anwar B, Munzil Ml, Arif H, (2017), Pengaruh Collaborative Learning Dengan Teknik Jumping Task Terhadap Keterampilan Berpikir Kritis Dan Hasil Belajar Siswa, Jurnal Pembelajaran Sains Univ. Negeri Malang, Vol 1, No 2 (2017).

Cerbin B\& Kopp B. (2009).A Brief Introduction to College Lesson Study.Lesson Study Project. (online: http://www.uwlax.edu/sotl/lsp/index2.htm

Gifford, M.C. \& Arvin, A. (2009).Sharing in teams of heterogeneous, collaborative learning agents. International Journal Of Intelligent Systems. 24. hlm. 173- 200

Kirschner Femke, Fred Paas and Paul A. Kirschner1, (2011). Task Complexity As A Driver For Collaborative Learning, http:// citeseerx.ist.psu.edu/ viewdoc/download?doi=10.1.1.1027.5111\&rep=rep1\&type=pdf, diakses 13 juli 2019.

Khotimah, R.P. \& Masduki. (2016). Improving Teaching Quality and Problem Solving Ability through Contextual Teaching and Learning in Differential Equations: A Lesson Study Approach. Journal of Research and Advances in Mathematics Education. 1(1), 1-13. http://journals.ums.ac.id/index.php/jramathedu.

Lewis, C. C., (2002).Lesson study: A Handbook of Teacher-Led Instructional Change. Philadelphia, PA: Research for Better Schools, Inc,

Manabu Sato. (2014). Mereformasi sekolah: konsep dan praktek komunitas belajar. Tokyo: Pelita.

Masaaki, Sato (2012). Dialog dan Kolaborasi di Sekolah Menengah Pertama. Edisi keTiga. Tokyo:Pelita-JICA.

Nofrion, (2017) Peningkatan Aktivitas Belajar Siswa Melalui Penerapan Metode "Jumping Task" Pada Pembelajaran Geografi, e-ISSN: 2549-7057 | p-ISSN: 2085-8167. Jurnal Geografi, Vol 9, No 1 (2017)

Rustaman, N.Y., dkk. (2003). Strategi Belajar Mengajar Biologi. Bandung: Jurusan Pendidikan Biologi FPMIPA UPI.

Rosbiono M. (2007) Teori Problem Solving Untuk Sains Direktorat Jendral Peningkatan Mutu Pendidik Dan Tenaga Kependidikan Depdiknas

Subadi, Tjipto. (2010). Lesson Study berbasis PTK (Penelitian Tindakan Kelas). Surakarta: Badan Penerbit FKIP UMS. 